\title{
Reading Habits and Attitude among the Seminar Librarians of University of Karachi
}

\author{
Rafat Parveen Siddiqui* \\ Farhat Hussain** \\ Sana Rahim*** \\ Nazeeha Asfreen****
}

\begin{abstract}
Reading is the most valuable among many habits of man. Some feel it as a source of pleasure and enjoyment and some consider it a wearisome activity. While a large number of people believe that it is need of time. This paper seeks to appraise the reading habits and attitude of seminar librarians of University of Karachi, Pakistan in terms of time, purpose, material and language. It is also an effort to know the Seminar Librarian's attitudes towards reading. To collect data, a questionnaire consists of three parts; personal information, reading habits, and reading attitude was designed and distributed among the targeted population. The collected data was analyzed and the result of findings is presented in the form of tables. From the total of 50 questionnaires distributed, 44 representing $88 \%$ were filled and returned. The findings show that majority of the seminar librarians having interest to read but not in form of printed book instead on internet. Only 36\% librarians considered reading as source of enjoyment.
\end{abstract}

\section{Keywords}

Reading Habits; Librarian; Seminar Librarian; University of Karachi; Reading Attitude

* Assistant Professor,

Department of Library \& Information Science, University of Karachi, Karachi

** Assistant Professor,

Department of Library \& Information Science, University of Karachi, Karachi

*** Assistant Professor,

Department of Library \& Information Science University of Karachi, Karachi

**** Department of Library \& Information Science University of Karachi, Karachi 


\section{Introduction}

This research study is about the reading habits and attitude of seminar librarians of University of Karachi, Pakistan. Before attempting to cope with the actual research topic, it seems necessary to know about reading, reading habits and reading attitude. It also needs to recognize the role and status of seminar library and librarians in a university then it can be explained that how much the habit of reading and positive reading attitude is necessary for them in a developing country like Pakistan.

Reading has been defined by Harvey and Goudvis ${ }^{1}$ as the process of thinking, understanding, evaluating and interpreting symbols and text. It is one of the good habits of civilized and literate people but for the librarian it is not only a quality but their obligation. Some people read for their inner satisfaction and they are used to do this as a daily activity. In view of some, reading is a boring hobby but may be compulsory when they have some specific purpose such as qualifying the examination or to participate in a competition etc.

Another definition by Green" "Reading is not only a source of getting better knowledge from other's experiences but it is also an exciting journey to selfdiscovery. Reading transfers experiences to the individual so that the reader may expand one's horizons, identify, extend and intensify his or her interest and gain deeper understanding of the world"

Reading is the understanding of written or printed words, which affects every part of life such as approaches, ethics, values, assessments and actions and reactions of readers. It is also a basis of valuable facts and it contributes extensively to job success, career growth, and aptitude to respond to change. Reading not only augments the mind but polishes the mind of the reader.

According to Krashen ${ }^{3}$, "The reading is helpful to develop a good writing style, an adequate vocabulary and advanced grammar in readers. One becomes excellent speller too because reading improves the language proficiency and makes the reader a better speaker".

1 Harvey, Stephanie, and Goudvis, Anne. Strategies that work. Portland, ME: Stenhouse, 2007. p.57.

2 Green, Pamela. Teachers intervention in children's reading. Journal of Childhood Education, Vol.46, no.3. 2002. pp. 147-149

3 Krashen, S. D. The Power of Reading. Englewood, CO: Libraries Unlimited, 1993. p. 91. 
"Reading is generally accepted as a way of acquiring new information and new knowledge. It is not only to increase knowledge but also to build maturity and widen awareness of contemporary issues." (Kim \& Anderson ${ }^{4}$ ).

Reading should not be confined to the things of one's interest but the reader should also be in search of new material and other subjects. Reading material can include books, fictions, stories, novels, magazines, newspapers, journals, etc. on subjects of interest and other topics.

Reading habit is simply habit of reading which is identified by Shen $^{5}$ as "how often, how much, and what the readers read". Cleary 6 defines reading habits as "an individual's interest to read which is determined by the considerable extent of the amount and intensity of pursuing the reading activity."

"A good reading habit is important for the development of personalities and mental capacities. This habit is necessary for a healthy intellectual growth and plays a very crucial role in enabling a person to achieve language proficiency" (Grabe \& Stoller ${ }^{7}$ ).

Reading is one of the most valuable habits among the many negative and positive habits of man. It works as an inbuilt tutor that we carry everywhere throughout our lives.

Reading attitude is defined by McKenna, Kear and Ellsworth ${ }^{8}$ "as a system of feelings related to reading which causes the learner to approach or avoid a reading situation".

4 Kim, J. Y. \& Anderson, T. Reading across the curriculum: A framework for improving the reading abilities and habits of college students. Journal of College Literacy and Learning, 37,2011. pp. 29-40.

5 Shen, L. Computer technology and college students' reading habits. Chia-Nan Annual Bulletin. Vol. 32. 2006. pp. 559-572.

6 Cleary, F. D. Blueprints for better reading: School programs for promoting skill and interest in reading. 2nd ed. New York: Wilson Co., 1972. p. 107.

7 Grabe, W. \& Stoller, F.L. Reading and Vocabulary Development in a Second Language: A case study. In Coady, J., and Huckin, T. N. (Eds.), Second Language Vocabulary Acquisition: A Rationale for Pedagogy. Cambridge: Cambridge University Press, 1997. pp. 98-122.

8 McKenna, C. M., Kear, D.J. \& Ellsworth, R. A. Children's Attitudes toward Reading: A National Survey. Reading Research Quarterly, Vol. 30, No. 4, 1995. pp. 934-955. 
Alexander \& Filler ${ }^{9}$ defined attitudes toward reading, "it is an individual's feeling about reading. It causes learners to adopt or avoid a reading situation".

People's attitude towards reading is entirely different from each other. Some enjoy reading and it is their favorite hobby, they feel reading is a source of enjoyment too. Some people believe that reading is important and the basis for their day-to-day activities as well as their working skills. On the other side, some people feel that it is a tedious activity, they are actually reluctant readers. While there is a number of people who are not used to reading for fun or pleasure but whenever they feel essential, they give it time and use it according to their need.

\section{Reading habits in Pakistan}

The reading habit brings significant improvement in the intellectual and conceptual intelligence and makes one proficient person. Reading habits of any nation depend upon literacy. Literacy promotes reading habits which creates demands of books and other hand, it demands to increase or improve publishing institutes. Here demand and supply theory can be observed.

Gallup Pakistan conducted survey under the topic "Reading Habits" on 28-29 December 2008 and concluded the results in percentage, only 27\% Pakistani said "Reading is my Habit" and remaining $73 \%$ do not read books that show low literacy rate in the country.

The revolution in technology changed the reading habits across the globe and book reading is becoming obsolete and CD, DVD, and Internet culture is becoming more and more popular. After the high-tech development and inflow of cellular phones, the new generation now mostly ignores books as the youths and children are engaged with other electronically-operated devices, softwares, and social media like mobile phones, computers, laptops, tablets, internet, Facebook, WhatsApp, and TV etc.

Government should restrict schools and colleges to follow the curricula which force students to use library. It is the only way to develop reading

9 Alexander, J. E., \& Filler, R. Attitudes and Reading. Newark, DE: International Reading Association, 1976. pp. 33-34. 
habits and use of libraries among students. The education should be librarybased and teachers should encourage students use books and libraries.

\section{Seminar libraries and librarians of University of Karachi}

A library is a service organization that can justify its existence only when it fulfills the information needs of its clients. Departmental or seminar libraries are collections of books, selected for the special use of a department or discipline, and usually kept in a convenient place in the building or section of the building devoted to that department.

A seminar library is a collection of books and other non-book material for the expediency of a particular department located apart from the main or central library. Recently the use of the term "seminar library" is synonymous with "departmental library".

University of Karachi, the biggest university of Pakistan, was established in 1951 through an Act of the parliament as a federal university. The varsity is now a widespread structure of 53 teaching and research departments and 20 world class and highly reputable Research Centers and Institutes, under nine faculties of Arts and Social Sciences, Science, Education, Law, Islamic Studies, Engineering, Management and Administrative Sciences, Pharmacy, and Medicine.

There are twenty one departments in faculty of Arts and Social Sciences, four in faculty of Pharmacy, four in Islamic Studies, three in Management and Administrative Sciences, three in Education, one each in Law, Engineering, and Medicine while the Science faculty consists of 20 departments and five research institutes. The central library of the university (Dr. Mahmud Husain Library) is one of the largest libraries in the country. Housed in spacious building, it has a collection of around 4 lac books, and over 110,000 copies of current and retrospective issues of national and foreign journals and periodicals covering a variety of disciplines and professional and subject fields.

Beside central library, every department also has its own seminar library equipped with the necessary books and other reading material. 
Jhss, Vol. 7, No. 2 , July to December, 2016

\section{Objectives of the study;}

The general objective of this study is to figure out the general nature of reading habits and attitudes of seminar librarians of University of Karachi. To explore the reading habits of seminar librarians, it endeavors to satisfy the following research questions:

a. How often the seminar librarians read?

b. What are their activities during leisure time?

c. How much time they spend on reading?

d. Which types of reading material they read?

e. What purpose they have to acquire from reading?

f. Which language they prefer for reading?

g. Which type and form of sources of information they are interested in?

h. What are their attitudes toward reading?

- Enjoyment ( reading for pleasure)

- Anxiety and difficulty( boring and hard to understand)

- Modality (other options for learning)

\section{Methodology}

The target population of the study-in-hand is seminar librarians of University of Karachi.

A questionnaire consists of three parts; personal information, reading habits, and reading attitude was used for the collection of data. The questionnaire was personally distributed to the population surveyed i.e. exclusively the seminar librarians, serving in different libraries within the University of Karachi.

A total of 50 questionnaires were distributed among the seminar librarians of different faculties especially faculties of Arts \& Social Sciences and Science and 44 filled-in questionnaires were received back, with a response rate of eighty eight percent. For the reading habits, six questions were asked about;

i) Reason for reading

ii) Their leisure time activity

iii) Preferred language to read

iv) How frequently do they read for leisure

v) Time duration to surfing internet in a day?

vi) Duration of playing games on computer/mobile in a day? 
For reading attitude, third part of the questionnaire contained eleven statements. The respondent's answered based on a four-point Likert-type scale (4 = "strongly agree"; 1 = "strongly disagree") that measured the three types of attitudes towards reading behavior. The three dimensions of reading attitude are stated below:

i) Reading activity and enjoyment (four items) measured the extent to which the person reads for pleasure.

ii) Anxiety and difficulty (five items) measured the extent to which the person experiences problems or becomes upset,

iii) Modality (two items) measured extent to which the individual prefers to use sources other than reading when faced with a learning task.

Simple percentage was used to analyze the data generated for easy interpretation and were presented in tables.

\section{Literature Review}

Many researches have been conducted on the topics like reading in general, reading habits and reading attitudes. Similarly some articles on departmental libraries are also identified. A number of studies have been done on reading habits and attitudes of different communities or group of people such as by gender, by profession or by specific subject specialists but seminar librarians have never been treated as focus of study.

McKenna, Kear \& Ellsworth ${ }^{10}$ suggest that "the individual's reading attitude develops over time as a result of three factors: (i) normative beliefs (how one's friends view about reading); (ii) beliefs about outcomes of reading (whether reading is likely to be pleasurable, useful, frustrating or boring) and beliefs about outcomes of competing activities; and (iii) specific reading experiences. The degree of positive or negative attitudes towards reading differs according to the kind of reading to be performed and the purpose of reading".

10 McKenna, C. M., Kear, D.J. \& Ellsworth, R. A. Children's Attitudes toward Reading: A National Survey. Reading Research Quarterly, Vol. 30, No. 4, 1995. pp. 934-955. 
Cook, Halleran \& O'Brien ${ }^{11}$ concluded that "reading provides readers great knowledge, understanding and a sense of values, which enables them gradually to develop the greatest of all virtues and the ability to understand other people beliefs".

Tella and Akande ${ }^{12}$ support the thought that the ability to read is at the heart of self-education and lifelong learning and that it is an art capable of transforming life and society..

Palani ${ }^{13}$ investigated the reading habit of teachers in India. He found out that male teachers read more than female teachers.

Muhammad Dilshad's (2013) study shows that female students have positive attitude towards reading as compare to male students. He recommended teachers to motivate and guide students toward reading habits, also suggested institutional libraries to ensure availability of printed and electronic collection for their students and create peaceful and attractive reading environment.

Ansari, , Panhwar \& Umrani ${ }^{14}$ explore that majority of students read textbooks daily, they do not read for pleasure. Students spend most of their time in academic in English for their assignments and projects. They rarely concerned other academic articles for reference.

Hassen ${ }^{15}$ explored the reading habit of high school teachers. According to her the high school teachers involved in this study admitted that reading is

11 Cook, Anne E., Halleran, Jennifer G. \& O'Brien, Edward J. What is readily available during reading? A memory-based view of text processing. Discourse processes. Vol. 26, No. $2 \& 3$. pp. 109-129.

12 Tella, A., \& Akande, S. Children's reading habits and availability of books in Botswana primary schools: Implications for achieving quality education, 2007. The Reading Matrix 7 (2) Available: http://www.readingmatrix.com/article/adeyinka/article/pdf

13 Palani, K. K. Promising Reading Habits and Creating Literate Social. International Reference Research Journal, Vol. III Issue 2(1). 2012. p 91.

14 Ansari, Sanaullah, Panhwar, Abdul Hameed \& Umrani, Sumera. Investigating ESL Learners' Reading Habits in a Pakistani University / ELF Annual Research Journal. Vol. 18. 2016. pp. 85-102.

15 Hassen, Rukya. Reading Habits of Secondary School Teachers: A Study of Selected Secondary Schools in Addis Ababa and Dessie. Journal of Education and Practice.Vol.7, No.22, 2016. pp.59-67. 
inevitable in their professional and personal lives; yet, it is overlooked. The common trend among the research participants is that they read by different push factors such as examinations, preparation of the regular classroom sessions. The researcher recommends for stakeholders to address this problem at a large-scale level including the causes to contribute for the improvement of these habits to help teachers survive as scholars and leaders of the country.

\section{Finding and Discussion}

The data from the questionnaires were classified and tabulated. The tabulated data depict the views of the respondents relating to their readings, reading habits and reading attitudes. The results of the study are presented in forms of tables below:

\section{Table-1 Demography of respondents}

\begin{tabular}{|l|c|l|c|}
\hline Gender & $\begin{array}{l}\text { Frequency } \\
\text { (N=44) }\end{array}$ & $\begin{array}{l}\text { Working in } \\
\text { (Faculty) }\end{array}$ & $\begin{array}{l}\text { Frequency } \\
\text { (N=44) }\end{array}$ \\
\hline Male & 10 & Social Science & 19 \\
\hline Female & 34 & Science & 20 \\
\hline & & Others & 05 \\
\hline
\end{tabular}

Table 1 shows that out of fifty respondents forty four answered and among them thirty four are female librarians and remaining ten are male. Of these 44 respondents, 19 belong to Faculty of Arts \& Social Science, 20 Faculty of Science, and remaining 5 other faculties like Education, and Pharmacy.

\section{Type of Reading Material}

The respondents were asked to identify the type of material they like most or the material they usually read. They had identified one or more than one types, so the percentage of the responses cannot be calculated. The following table shows the material they are interested in:

Table -2 Types of reading material

\begin{tabular}{|c|c|}
\hline Type/Form of Material & Frequency \\
\hline News paper & 35 \\
\hline $\begin{array}{l}\text { Academic } \quad \text { Books/text } \\
\text { Books }\end{array}$ & 19 \\
\hline
\end{tabular}




\begin{tabular}{|l|c|}
\hline Websites & 16 \\
\hline Magazines & 18 \\
\hline Fiction (Novels/stories) & 23 \\
\hline Journals/Periodicals & 8 \\
\hline Other forms of Literature & 10 \\
\hline
\end{tabular}

Types of documents read by the participants shown in table 2,indicate that nearly all respondents ranked newspapers on a top priority. Preferred secondly by the respondents are books, fiction and then general and academic books, followed by magazines. Beside the fiction, other forms of literature such as travelogues, biographies and poetry are also their field of interest. Current periodicals / journals are at low priority by the respondents. There are also 16 participants who visit different websites to read their required material.

\section{Average Time Spending on Reading}

Different respondents spend different time span on reading. They manage to spare some time to read something on daily basis. The following table shows how much time they spend on reading per day.

Table 3: $\quad$ Time Spent on Reading per Day

\begin{tabular}{|l|c|c|}
\hline Time & Frequency & Percentage \\
\hline Less than 1 hour & 09 & $20.4 \%$ \\
\hline 1-2 hours & 21 & $47.7 \%$ \\
\hline 2-3 hours & 09 & $20.4 \%$ \\
\hline 3-4 hours & 03 & $06.8 \%$ \\
\hline More than 4 hours & 02 & $04.5 \%$ \\
\hline
\end{tabular}

The table indicates that majority of the readers i.e. 21 (47.7\%) spends one to two hour daily for reading any type of printed sources. The number of the respondents which spends either less than one hour or two to three hours is equal i.e. $9(20.4 \%)$.

\section{Sources of Reading Material}

The source of material which is more frequently used by the respondents varies from reader to reader. If they are financially strong, they purchase 
books or other reading material otherwise depend on borrowing from a library, or friends or relatives. The following table shows the status:

Table 4: $\quad$ Source of Reading material

\begin{tabular}{|l|c|c|}
\hline Source & Frequency & Percentage \\
\hline Library & 23 & $52.2 \%$ \\
\hline Bookshops & 11 & $25.0 \%$ \\
\hline Friends & 08 & $18.2 \%$ \\
\hline Others & 02 & $04.5 \%$ \\
\hline
\end{tabular}

It is found from the table that majority of the respondents i.e. 23 (52.2\%) reads library books, whereas a reasonable number i.e. 25 percent can afford and purchases from the bookshops or book fairs and exhibitions where the reading material is available on very discounted rates.

\section{Reason for Reading}

No doubt, people read books and other reading material for a reason or another. Some read to meet a need whereas some read for enjoyment or satisfy their reading habits. The following table shows different reasons of reading as described by the participants:

Table 5: Reason for reading

\begin{tabular}{|l|c|c|}
\hline Reason & Frequency & Percentage \\
\hline Qualify Exam./Test & 06 & $13.6 \%$ \\
\hline Interested in Topic & 20 & $45.5 \%$ \\
\hline Relaxing oneself & 13 & $29.5 \%$ \\
\hline For fun/entertainment & 05 & $11.4 \%$ \\
\hline
\end{tabular}

Table 5 reveals different reasons behind their reading. Majority i.e. 45.5 percent observes that they read if they find their topic of interest in any material. Thirteen participants $(29.5 \%)$ think that they get relaxation from reading. Only 6 participants are of the view that they read only when they have to appear in an examination, test or interview, otherwise they rarely turn towards reading. This situation shows the poor reading culture among the librarians. The concept of reading for pleasure does not exist even in librarians although they are responsible to lead the society for reading. They read by some push factors not as habitual reader. 


\section{Favorite Activity/Activities in Leisure Time}

Doing different activities/chores during spare time is the nature of human beings. Some people utilize their leisure time in some constructive pursuits and some in negative or futile activities. The following table shows these activities of the respondents. As the respondents have one or more activities during their leisure time, the frequency will vary.

\section{Table 6: $\quad$ Favorite activity in leisure time}

\begin{tabular}{|l|c|}
\hline Activities & Frequency \\
\hline Reading Books etc. & 26 \\
\hline Surfing Internet & 16 \\
\hline $\begin{array}{l}\text { Playing Games } \\
\text { (Mobile/Computer) }\end{array}$ & 06 \\
\hline Using Facebook & 08 \\
\hline Watching Movies & 06 \\
\hline
\end{tabular}

Majority of the participants prefers to read books during their free time, but such respondents also resort to certain other activities like surfing internet or usingFacebook. The other activities include playing mobile/computer games, and watching movies. .

\section{Language Preference for Reading}

Language of the reading material matters a lot, as reader feels comfortable with any language of his/her choice. The following table shows the interest of the participants in the language they prefer to read in:

\section{Table 7: Language Preference for reading}

\begin{tabular}{|l|c|c|}
\hline Source & Frequency & Percentage \\
\hline Urdu & 19 & $43.2 \%$ \\
\hline English & 11 & $25.0 \%$ \\
\hline Urdu + English & 11 & $25.0 \%$ \\
\hline Others (Sindhi) & 03 & $06.8 \%$ \\
\hline
\end{tabular}

The table shows that majority of the participants i.e. 19 (43.2 percent) prefer to read in their national language Urdu. Those whose preference is only 
English or English and Urdu both are equal i.e. 11 (25 percent) whereas there are only 3 (6.8 percent) who read in Sindhi language.

\section{Checking Facebook Account}

Use of social media is very much active in the society and seminar librarians are no exception. They also have their Facebook, Twitter, and Instagram accounts. They were inquired about their practice of using the most popular Facebook. The following table indicates how often or when they log on to their social media account.

Table 8:How often theFacebook account is checked

\begin{tabular}{|l|c|c|}
\hline Response & Frequency & Percentage \\
\hline At the time of boredom & 29 & $65.9 \%$ \\
\hline $\begin{array}{l}\text { When logged on to } \\
\text { internet }\end{array}$ & 08 & $18.1 \%$ \\
\hline All the time Facebook & 04 & $06.8 \%$ \\
\hline $\begin{array}{l}\text { Have no } \\
\text { account }\end{array}$ & $09.1 \%$ \\
\hline
\end{tabular}

The table shows that majority of the respondents i.e. 29 (about 66 percent) use or check their Facebook account whenever they feel boredom and 8 respondents (18.1 percent) check it when they are logged on to internet. Interestingly there are 9 percent of the respondents who do not have any Facebook account while the remaining (around 7 percent) are busy all the time on Facebook chatting on mobile phones.

\section{Time Spending on Internet}

Today's most common activity of the people is to go around with internet whether through laptop, computer, or mobile phone. The participants were inquired about the time they spend on internet daily for fun.

Table 9: Time Spent on Internet for fun every day

\begin{tabular}{|l|c|c|}
\hline Time Duration & Frequency & Percentage \\
\hline Less than 1 Hour & 28 & $63.6 \%$ \\
\hline 1-2 Hours & 11 & $25.0 \%$ \\
\hline 2-3 Hours & 04 & $09.1 \%$ \\
\hline 3-4 Hours & 01 & $02.3 \%$ \\
\hline More than 4 Hours & 00 & $00.0 \%$ \\
\hline
\end{tabular}


The table traces out the surprising results that the majority (63.6\%) of the respondents is spending only one or less than one hour a day and there are only 2.3 percent who use internet almost four hours daily.

\section{Time Spending on Playing Online Games}

This is another popular activity of majority of the youths now-a-days. Some give justification in its favor and term it a mental exercise which is helpful in developing intellect and understanding whereas the opponents criticize and term it a big hurdle in the physical health of human body as the bodily exercise comes to an end due to it.

Table 10: Time Spent on Playing Online Games a Day

\begin{tabular}{|l|c|c|}
\hline Time Duration & Frequency & Percentage \\
\hline Less than 1 hour & 37 & $84.1 \%$ \\
\hline 1-2 hours & 06 & $13.6 \%$ \\
\hline 2-3 hours & 01 & $02.2 \%$ \\
\hline More than 3 hours & 00 & $00.0 \%$ \\
\hline
\end{tabular}

The table indicates seemingly an unreal figure that the majority of the respondents $(84.1 \%)$ spends only one hour on playing online games and more than thirteen percent spend one to two hours daily for this fun. None of them accept to utilize more than three hours for the purpose.

\section{Reading Attitude}

People read something for a variety of reasons and as a result of their reading, their behavior and attitude also develops. Some read for pleasure and they feel and behave accordingly, some are scared to reading and feel difficulty in finishing an article, essay, or book and their feelings are apparent from their attitude, whereas there are some who find intermediary way to replace reading a book or other material with something else. The following table shows reading attitude of the respondents:

Table 13 Reading Attitude of the Participants

\begin{tabular}{|l|c|c|}
\hline Attitude & Frequency & Percentage \\
\hline $\begin{array}{l}\text { Enjoyment ( reading for } \\
\text { pleasure) }\end{array}$ & 16 & 36 \\
\hline Anxiety and Difficulty & 08 & 18 \\
\hline Modality & 20 & 45 \\
\hline
\end{tabular}


To measure the reading attitude of the respondents, three variables were used in the study (i.e. Enjoyment, Anxiety and Difficulty, and Modality). For the variable "Enjoyment", the following four statements were upheld by the respondents:

1) Reading is one of my preferred pursuits

2) I devote much of my spare time in reading

3) I want to have more books of my own

4) I get a lot of enjoyment from reading

A reasonable number of the respondents i.e. 16 (36 percent) supported these four statements, so their attitude was "Enjoyment".

For the variable "Anxiety and Difficulty", the following five statements were endorsed by the respondents:

1) I get upset when I think about having to read

2) When I read, I usually get tired and sleepy

3) I often feel anxious when I have a lot of reading to do

4) I try very hard to read, but I find reading boring.

5) I abruptly disremember what I have read even if I have just read it.

There were 18 percent respondents who had maintained these statements, hence have been kept under the attitude of "Anxiety and Difficulty".

The following two statements were advocated by the respondents for the variable "Modality":

1) There are other better ways to learn new things than by reading a book.

2) Reading is one of the best ways for me to learn some things.

Majority of the participants i.e. 20 (45 percent) backed these two statements which shows their attitude as Modality.

\section{Conclusion}

This study was conducted as an attempt to enhance understanding about reading habits and attitude of seminar librarians working in different departmental libraries of University of Karachi. For this purpose fifty participants were contacted and questionnaires were distributed to them. Of them, forty four responded and filled the questionnaires. The overall result indicates that these librarians spend quite a significant amount of time to 
surfing the Internet, playing computer/mobile games and other technologyrelated activities as compared to reading. Reading is only regarded as a secondary activity during their leisure time. The majority spends only an hour a day on reading which is an alarming situation especially for the working librarian. As for as the reading attitude is concerned, findings reveal a different picture that $36 \%$ librarians enjoy reading as much as other activities. 18\% librarians find reading as difficult and causing anxiety. They also think that besides the reading there are so many other modern and easy access sources to learn new things. They feel reading is boring and unmotivated apathetic for them. Most of the librarians i.e. $45 \%$ have moderate attitude towards reading. 


\section{Reference}

Alexander, J. E., \& Filler, R. Attitudes and Reading. Newark, DE: International Reading Association, 1976.

Ansari, Sanaullah, Panhwar, Abdul Hameed \& Umrani, Sumera. Investigating ESL Learners' Reading Habits in a Pakistani University / ELF Annual Research Journal. Vol. 18. 2016. pp. 85-102.

Cleary, F. D. Blueprints for better reading: School programs for promoting skill and interest in reading.2nd ed. New York: Wilson Co., 1972.

Cook, Anne E., Halleran, Jennifer G. \& O'Brien, Edward J. What is readily available during reading? A memory-based view of text processing. Discourse processes. Vol. 26, No. 2\&3. pp. 109-129.

Dilshad, M. \& Ali, A. \&Akram, A.(2013). Gender Differences in Reading Habits of University Students: an evidence from Pakistan. Pakistan Journal of Social Sciences (PJSS),Vol. 33, no. 2. 2013. pp. 311-320.

Grabe, W., \& Stoller, F.L. Reading and Vocabulary Development in a Second Language: A case study. In Coady, J., and Huckin, T. N. (Eds.), Second Language Vocabulary Acquisition: A Rationale for Pedagogy. Cambridge: Cambridge University Press, 1997. pp. 98-122.

Green, Pamela. Teachers intervention in children's reading. Journal of Child Hood Education, Vol.46, no.3. 2002. pp. 147-149

Harvey, Stephanie, and Anne Goudvis, Anne. Strategies that work. Portland, ME: Stenhouse, 2007.

Hassen, Rukya. Reading Habits of Secondary School Teachers: A Study of Selected Secondary Schools in Addis Ababa and Dessie Journal of Education and Practice.Vol.7, No.22. 2016. pp.59-67

Kim, J. Y., \& Anderson, T. Reading across the curriculum: A framework for improving the reading abilities and habits of college students. Journal of College Literacy and Learning, 37, 2011. pp. 29-40.

Krashen, S. D. The Power of Reading. Englewood, CO: Libraries Unlimited, 1993. 
McKenna, C. M. \&Kear, D.J. \& Ellsworth, R. A. Children's Attitudes toward Reading: A National Survey. Reading Research Quarterly, Vol. 30, No. 4, 1995. pp. 934-955

Mokhtari ,Kouider. Reichard, Carla A. \& Gardner, Anne. The Impact of Internet and Television Use on the Reading Habits and Practices of College Students. Journal of Adolescent \& Adult Literacy Vol. 52, no. 7. 2009. pp. 609619.

Palani, K. K. Promising Reading Habits and Creating Literate Social. International Reference Research Journal ,Vol. III Issue 2(1). 2012. p 91.

Shakeel A. K. \&Shafique, F. Role of departmental library in satisfying the information needs of students: a survey of two of departments of Islamia University of Bahawalpur. Pakistan Journal of Library \& Information Science. 2011. 1-6.

Shen, L. Computer technology and college students' reading habits.Chia-Nan Annual Bulletin. Vol. 32. 2006. pp. 559-572.

Tella, A., \&Akande, S. Children's reading habits and availability of books in Botswana primary schools: Implications for achieving quality education. The Reading Matrix 7 (2). 2007. Available: http://www.readingmatrix.com /article/adeyinka/article/pdf

Thompson,Lawrence. The historical background of departmental and collegiate libraries (http://www.journals.uchicago.edu/t-and-c).downloaded from 111.068.108.075 on March 06, 2018 01:13:44 AM

Liu, Ziming. Reading behavior in the digital environment: Changes in reading behavior over the past ten years.Journal of Documentation, Vol. 61 Issue: 6, 2005. pp.700-712. 